\title{
Effect of Nb on the Proof Strength of Ferritic Stainless Steels at Elevated Temperatures
}

\author{
Atsushi MIYAZAKI, Kenji TAKAO and Osamu FURUKIMI \\ Technical Research Laboratories, Kawasaki Steel Corporation, Kawasakicho, Chuo-ku, Chiba 260-0835 Japan.
}

(Received on January 23, 2002; accepted in final form on May 14, 2002)

The effect of $\mathrm{Nb}$ on the high temperature proof strength of $0.46 \% \mathrm{Nb}$-added ferritic stainless steel was studied from the viewpoints of solid solution strengthening, precipitation strengthening, and precipitation strengthening during tensile test and/or preceding hold time. The results obtained were as follows.

(1) The increase in high temperature proof strength in Nb-added ferritic stainless steel is particularly remarkable at around $700^{\circ} \mathrm{C}$ in comparison with that in Ti-added steels.

(2) After aging treatment for $2 \mathrm{~h}$ at $700^{\circ} \mathrm{C}$, in addition to the approximately $0.14 \%$ content of coarse $\mathrm{Nb}$ carbides and nitrides which had precipitated before this aging treatment, fine $\mathrm{Fe}_{2} \mathrm{Nb}$ Laves phase particles with a size of $0.02 \mu \mathrm{m}$ precipitated out in an amount of approximately $0.3 \%$, and virtually no solid solution $\mathrm{Nb}$ existed in the steel. The $700^{\circ} \mathrm{C}$ proof strength in this condition showed a value near the $700^{\circ} \mathrm{C}$ proof strength before the aging treatment, that is, when approximately $0.3 \%$ solid solution $\mathrm{Nb}$ was present.

(3) When aging treatment is performed at $700^{\circ} \mathrm{C}$ for $2 \mathrm{~h}$ or more, virtually all the added Nb precipitates out. The coarsening of the $\mathrm{Fe}_{2} \mathrm{Nb}$ laves phase particles within the range of $0.02-0.05 \mu \mathrm{m}$ during aging at $700^{\circ} \mathrm{C}$ greatly decreases the high temperature proof strength at $700^{\circ} \mathrm{C}$.

(4) Cold rolled steel sheets of Nb-added ferritic stainless steel are normally manufactured by annealing at a temperature of $900^{\circ} \mathrm{C}$ or higher in order to cause recrystallization. Accordingly, before measurement of the proof strength at $700^{\circ} \mathrm{C}$, the steel contains a large quantity of solid solution $\mathrm{Nb}$. The phenomenon of particularly high strength at $700^{\circ} \mathrm{C}$ is considered to be attributable to the precipitation of this solid solution $\mathrm{Nb}$ as a fine $\mathrm{Fe}_{2} \mathrm{Nb}$ Laves phase during the tensile test and/or preceding hold time.

KEY WORDS: stainless steel; Laves phase; proof strength at elevated temperatures.

\section{Introduction}

Purification of automotive exhaust gas has been a subject of intense study in recent years due to public concern about global environmental problems. Increasing the temperature of the exhaust gas tends to activate the catalyst and is therefore considered an effective means of improving the gas purification ratio. ${ }^{1)}$ At present, many automotive exhaust system parts such as the exhaust manifold, front pipe, and converter shell are produced from SUH409L $(11 \% \mathrm{Cr}-\mathrm{Ti})$ or SUS410L $(12 \% \mathrm{Cr})$ with a sheet thickness of $1-2 \mathrm{~mm}$. However, from the viewpoint of preventing buckling and improving high temperature fatigue properties, there has been a growing need for a material with improved proof strength at elevated temperatures. ${ }^{2,3}$ ) For this reason, Nbadded ferritic stainless steels have been developed, ${ }^{4-7)}$ as these steels possess excellent high temperature proof strength and oxidation resistance. It has been reported ${ }^{5,6,8)}$ that the proof strength of $\mathrm{Nb}$-added stainless steels is higher than that of SUS409L and SUS410L in the temperature region of $600-900^{\circ} \mathrm{C}$. In particular, it should be noted that the proof strength of $\mathrm{Nb}$-added steels is exceptionally high at temperatures around $700^{\circ} \mathrm{C}$. However, the strengthening mechanism at temperatures around $700^{\circ} \mathrm{C}$, where this unique high strength phenomena is observed, has not been elucidated.

In this paper, the authors studied the effect of $\mathrm{Nb}$ on high temperature proof strength, particularly at $700^{\circ} \mathrm{C}$, with special attention to the $\mathrm{Nb}$ precipitates, including $\mathrm{Nb}$ precipitation during tensile test and/or preceding hold at $700^{\circ} \mathrm{C}$ and solid solution $\mathrm{Nb}$.

\section{Test Specimens and Experimental Procedure}

\subsection{Test Specimens}

The test materials were $15 \% \mathrm{Cr}$ ferritic stainless steels with $\mathrm{Nb}$ addition in the range of $0-0.7 \%$. The same base steel with $0.21 \%$ and $0.37 \%$ Ti addition was used for comparison. Test specimens were prepared by vacuum melting to $50 \mathrm{~kg}$ ingots. The chemistry of the materials tested is shown in Table 1. Because the $\mathrm{C}$ and $\mathrm{N}$ contents were reduced while the Si content was increased, the materials consisted of a ferritic single phase regardless of the heat treatment conditions applied in these experiments. The microstructures were confirmed with an optical microscope. The ingots were hot forged to a sheet thickness of $27 \mathrm{~mm}$, and after holding at $1150^{\circ} \mathrm{C}$ for $1 \mathrm{~h}$, were hot rolled to a thickness of $5 \mathrm{~mm}$ and water cooled. The annealing temperatures were $1000^{\circ} \mathrm{C}$ and $900^{\circ} \mathrm{C}$ for the $\mathrm{Nb}$-added steels and the other steels, respectively in order to produce fully re- 
crystallized grain structure. After holding for $5 \mathrm{~min}$ to recrystallize the steels, the sheets were air cooled. These hot rolled sheets were then cold rolled to a sheet thickness of 2 $\mathrm{mm}$. After cold rolling, recrystallization annealing was performed by holding the Ti-added steel and $\mathrm{Nb}$ - and Ti-free steels at $900^{\circ} \mathrm{C}$ for $60 \mathrm{sec}$, holding the $0.3 \% \mathrm{Nb}$-added steel at $950^{\circ} \mathrm{C}$ for $60 \mathrm{sec}$, and holding the $0.5 \% \mathrm{Nb}$-added steel and $0.7 \% \mathrm{Nb}$-added steel at $1000^{\circ} \mathrm{C}$ for $60 \mathrm{sec}$ in order to produce fully recrystallized grain structure with the same grain size. Test materials were also prepared by performing additional aging treatment of the cold rolled and annealed sheets at $700^{\circ} \mathrm{C}$ for times ranging from $2 \mathrm{~h}$ to $10 \mathrm{~h}$ in order to investigate the $\mathrm{Nb}$ precipitation behavior.

\subsection{Experimental Procedure}

A high temperature tensile test was performed in the temperature range from $200^{\circ} \mathrm{C}$ to $900^{\circ} \mathrm{C}$. After heating to the specified temperature, the test pieces were held for 20 min, and $0.2 \%$ proof strength was measured at a strain rate of $0.3 \% / \mathrm{min}$. The configuration of the test pieces is shown in Fig. 1. In order to study the effect of precipitates on high temperature proof strength, precipitates were identified by observation with a transmission electron microscope (TEM) equipped with an energy dispersion X-ray (EDX) spectroscope. Identification was also performed by quantitative chemical analysis of the residue after electrolytic extraction using an acetyl-acetone type solution and by X-ray diffraction analysis.

\section{Experimental Results}

\subsection{Effect of Nb on High Temperature Proof Strength}

The $0.2 \%$ proof strength of the $15 \% \mathrm{Cr}-0.5 \% \mathrm{Nb}$ steel and $15 \% \mathrm{Cr}-0.4 \% \mathrm{Ti}$ steel at temperatures from Room Temperature(RT) to $900^{\circ} \mathrm{C}$ is shown in Fig. 2 At all temperatures, $0.2 \%$ proof strength is improved by $\mathrm{Nb}$ addition. Figure 3 shows the $0.2 \%$ proof strength ratio of the $15 \% \mathrm{Cr}-0.5 \% \mathrm{Nb}$ steel to the $15 \% \mathrm{Cr}-0.4 \% \mathrm{Ti}$ material for estimating the degree of improvement at each temperature.

Table 1. Chemical compositions of specimens (mass\%).

\begin{tabular}{lcccccc}
\hline \hline \multicolumn{1}{c}{ Steel } & $\mathrm{C}$ & $\mathrm{Si}$ & $\mathrm{Cr}$ & $\mathrm{Nb}$ & $\mathrm{Ti}$ & $\mathrm{N}$ \\
\hline $15 \mathrm{Cr}$ & 0.004 & 0.81 & 15.0 & - & - & 0.009 \\
$15 \mathrm{Cr}-0.3 \mathrm{Nb}$ & 0.006 & 0.82 & 14.9 & 0.27 & - & 0.008 \\
$15 \mathrm{Cr}-0.5 \mathrm{Nb}$ & 0.008 & 0.84 & 15.1 & 0.46 & - & 0.007 \\
$15 \mathrm{Cr}-0.7 \mathrm{Nb}$ & 0.007 & 0.83 & 14.9 & 0.69 & - & 0.008 \\
$15 \mathrm{Cr}-0.2 \mathrm{Ti}$ & 0.006 & 0.81 & 15.0 & - & 0.21 & 0.009 \\
$15 \mathrm{Cr}-0.4 \mathrm{Ti}$ & 0.007 & 0.82 & 15.1 & - & 0.37 & 0.007 \\
\hline
\end{tabular}

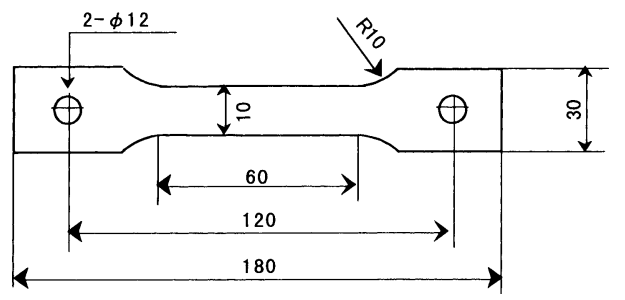

Fig. 1. Dimension of specimens (mm). (thickness: $2 \mathrm{~mm}$ )
The test results by Utsunomiya ${ }^{5)}$ et al. were plotted in Fig. 3 , together with the results of this work. The $0.2 \%$ proof strength ratio of $\mathrm{Nb}$-added stainless steels is extremely high at temperatures around $700^{\circ} \mathrm{C}$. Figure 4 shows the effect of $\mathrm{Nb}$ addition on the $0.2 \%$ proof strength of the $15 \% \mathrm{Cr}$ steels at $700^{\circ} \mathrm{C}$. For comparison, the values for Ti-added steels are also shown. The effect of $\mathrm{Nb}$ addition on $0.2 \%$ proof strength at $700^{\circ} \mathrm{C}$ is also remarkable in comparison with that of $\mathrm{Ti}$ addition. Based on these findings, the strengthening mechanism was studied as described in the following using the $15 \% \mathrm{Cr}-0.5 \% \mathrm{Nb}$ steel.

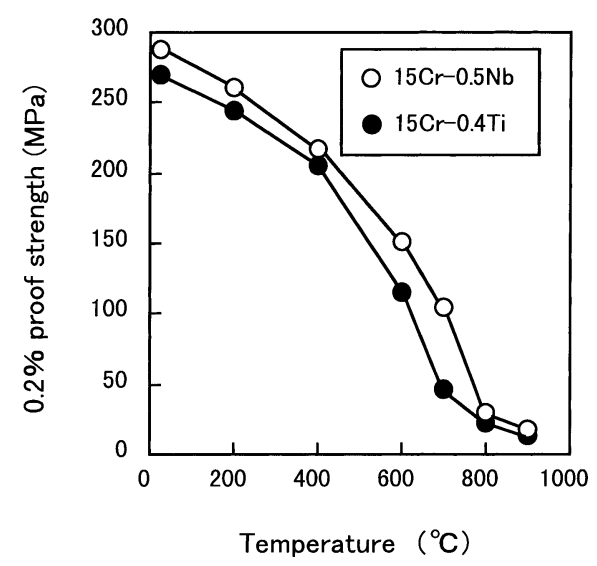

Fig. 2. $0.2 \%$ proof strength of ferritic stainlesss steels at temperatures from RT to $900^{\circ} \mathrm{C}$.

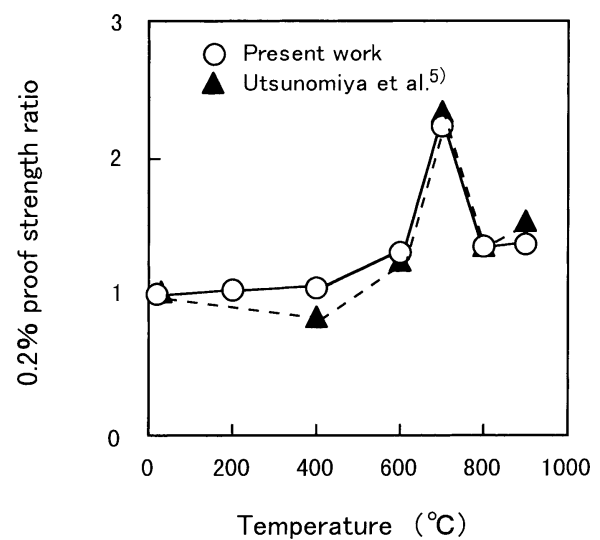

Fig. 3. $0.2 \%$ proof strength ratio of the $15 \mathrm{Cr}-0.5 \mathrm{Nb}$ and $12 \mathrm{Cr}-0.6 \mathrm{Nb}^{5)}$ steels to the $15 \mathrm{Cr}-0.4 \mathrm{Ti}$ steel at temperatures from RT to $900^{\circ} \mathrm{C}$.

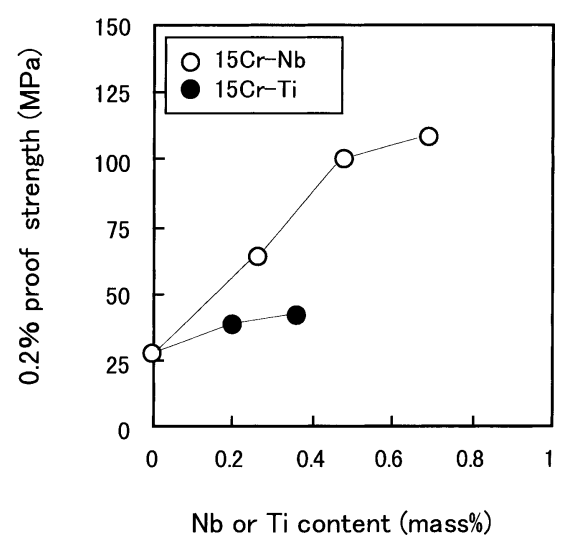

Fig. 4. Effects of $\mathrm{Nb}$ and $\mathrm{Ti}$ contents on $0.2 \%$ proof strength at $700^{\circ} \mathrm{C}$. 


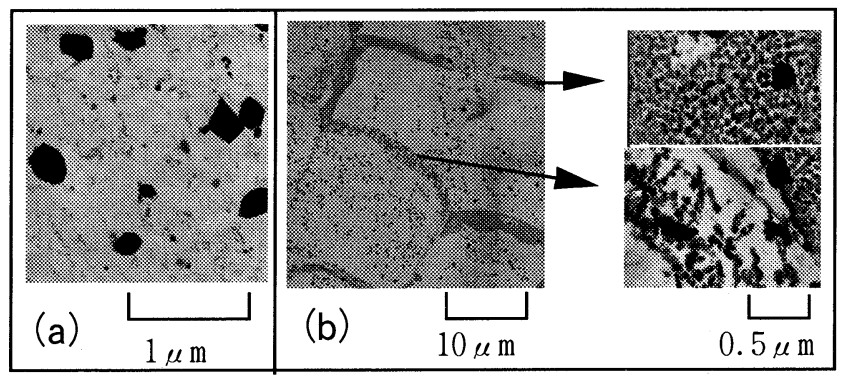

Fig. 5. Transmissiion electron micrographs of $15 \mathrm{Cr}-0.5 \mathrm{Nb}$ steel; (a) before tensile test and (b) after tensile test with $0.2 \%$ strain at $700^{\circ} \mathrm{C}$.

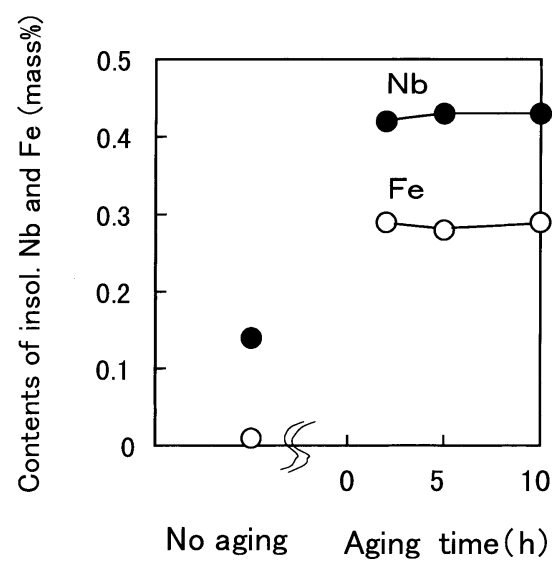

Fig. 6. Influence of aging time at $700^{\circ} \mathrm{C}$ on contents of insol. $\mathrm{Nb}$ and insol.Fe.

\subsection{Precipitates and TEM Microstructure before and after Tensile Test}

Figure 5 shows the TEM microstructures of a cold rolled and annealed sheet of $15 \% \mathrm{Cr}-0.5 \% \mathrm{Nb}$ steel and the same steel after applying $0.2 \%$ nominal strain at $700^{\circ} \mathrm{C}$, followed by air cooling. Before the tensile test, mainly coarse precipitates in the size rage of $0.1-0.3 \mu \mathrm{m}$ were observed. On the other hand, in the microstructure after $0.2 \%$ nominal strain at $700^{\circ} \mathrm{C}$, in addition to the coarse precipitates that were present before tensioning, a large quantity of fine precipitates with a size on the order of $0.03 \mu \mathrm{m}$ were also observed. $\mathrm{Nb}$ and $\mathrm{Fe}$ peaks were observed for fine precipitates in EDX analysis. On the other hand, $\mathrm{Nb}$ peak was observed and Fe peak was not observed for the coarse precipitates in EDX analysis. The fine precipitates seem to have an effect on $0.2 \%$ proof strength at $700^{\circ} \mathrm{C}$. However, the fine precipitates could not be identified by the electron diffraction pattern due to their fine sizes.

\subsection{Precipitates and TEM Microstructure after Aging}

Figure 6 shows the effect of aging time at $700^{\circ} \mathrm{C}$ on the contents of precipitated $\mathrm{Nb}$ and $\mathrm{Fe}$, which were measured by electrolytic extraction from cold rolled and annealed sheets of $15 \% \mathrm{Cr}-0.5 \% \mathrm{Nb}$ steel. Precipitation of both $\mathrm{Nb}$ and $\mathrm{Fe}$ reached saturation after aging treatment for $2 \mathrm{~h}$. As shown in Fig. 6, the increased content of precipitates attributable to aging was $0.29 \mathrm{mass} \%$ in the case of $\mathrm{Nb}$ and 0.28 mass $\%$ in the case of Fe. Figure 7 shows the results of Xray diffraction analysis. The X-ray diffraction analysis of the electrolytic extraction residue showed only an extremely

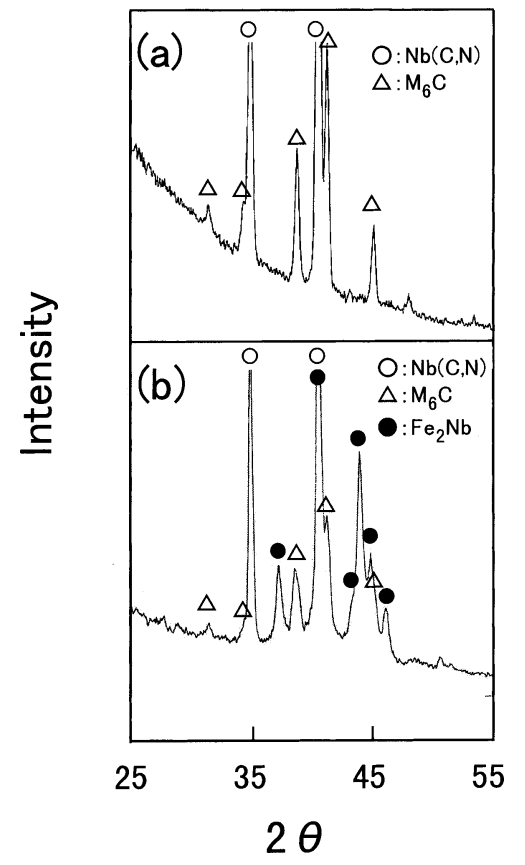

Fig. 7. X-ray diffraction pattern of residues extracted from $15 \mathrm{Cr}-0.5 \mathrm{Nb}$ steel; (a) annealed at $1000^{\circ} \mathrm{C}$ for $60 \mathrm{~s}$ and (b) aged at $700^{\circ} \mathrm{C}$ for $2 \mathrm{~h}$ after annealing at $1000^{\circ} \mathrm{C}$ for $60 \mathrm{~s}$.

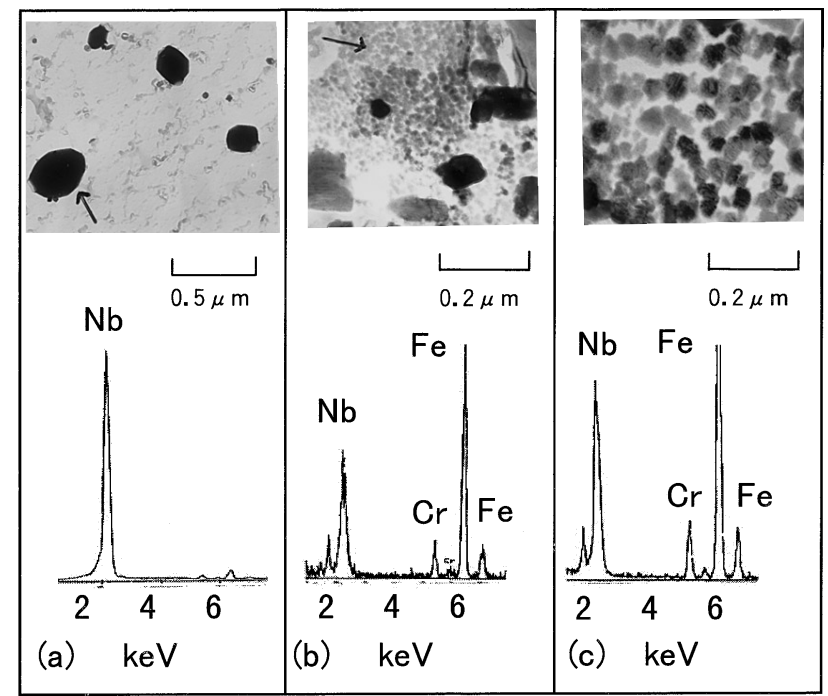

Fig. 8. Transmission electron micrographs; (a) annealed at $1000^{\circ} \mathrm{C}$ for $60 \mathrm{~s}$, (b) aged at $700^{\circ} \mathrm{C}$ for $2 \mathrm{~h}$ after annealing at $1000^{\circ} \mathrm{C}$ for $60 \mathrm{~s}$, and (c) aged at $700^{\circ} \mathrm{C}$ for $10 \mathrm{~h}$ after annealing at $1000^{\circ} \mathrm{C}$ for $60 \mathrm{~s}$.

strong diffraction peak for $\mathrm{Nb}(\mathrm{C}, \mathrm{N})$ and an weak diffraction peak for $\mathrm{M}_{6} \mathrm{C}$ in the cold rolled and annealed steel that was not given aging treatment. On the other hand, when aging was performed at $700^{\circ} \mathrm{C}$ for $2 \mathrm{~h}$ or more, a strong diffraction peak for $\mathrm{Fe}_{2} \mathrm{Nb}$ Laves phase was also observed in addition to the above-mentioned precipitates. The effect of $\mathrm{Fe}_{2} \mathrm{Nb}$ Laves phase on the proof strength was discussed in Sec. 4.

Figure 8 shows the TEM microstructure of cold rolled and annealed steels before and after aging at $700^{\circ} \mathrm{C}$. In the cold rolled and annealed steel before aging, mainly coarse precipitates in the size range of $0.1-0.3 \mu \mathrm{m}$ were observed as described in Sec. 3.2. It was concluded that these precip- 


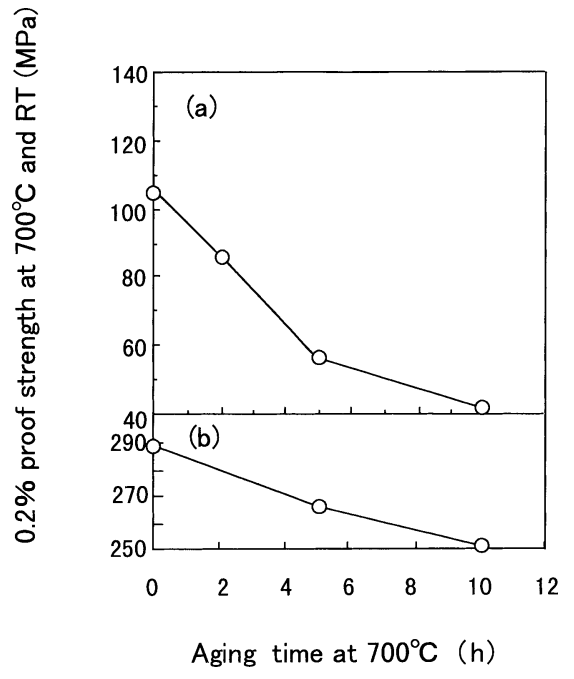

Fig. 9. Influence of aging time at $700^{\circ} \mathrm{C}$ prior to tensile test on $0.2 \%$ proof strength at (a) $700^{\circ} \mathrm{C}$ and (b) RT.

itates were $\mathrm{Nb}(\mathrm{C}, \mathrm{N})$ by EDX analysis and X-ray diffraction analysis of the electrolytic extraction residue shown in Figs. 7(a) and 8(a). The TEM microstructures of the cold rolled and annealed steels that were aged at $700^{\circ} \mathrm{C}$ for $2 \mathrm{~h}$ and for $10 \mathrm{~h}$ are shown in Figs. 8(b) and 8(c), respectively. In the material that was aged for $2 \mathrm{~h}$, in addition to the coarse precipitates with sizes of approximately $0.1 \mu \mathrm{m}$, which existed in the non-aged material, a large quantity of fine precipitates in the size range of $0.02 \mu \mathrm{m}$ or smaller were also observed. Coarsening of the size of these precipitates to 0.05 $\mu \mathrm{m}$ was observed in the material that was aged for $10 \mathrm{~h}$.

\subsection{Effect of Aging Time on $0.2 \%$ Proof Strength at $7^{\circ} 0^{\circ} \mathrm{C}$ and Room Temperature (RT)}

Figure 9 shows the effect of aging time at $700^{\circ} \mathrm{C}$ on the $0.2 \%$ proof strength at $700^{\circ} \mathrm{C}$ and RT. Aging for $10 \mathrm{~h}$ reduced the proof strength at $700^{\circ} \mathrm{C}$ by approximately 60 $\mathrm{MPa}$, to a value about half that before aging. In contrast, aging for $10 \mathrm{~h}$ reduced the proof strength at RT by only approximately $40 \mathrm{MPa}$.

\subsection{Effect of Reheating after Aging}

If the $\mathrm{Nb}$-precipitates which formed during aging treatment at $700^{\circ} \mathrm{C}$ are again heated to a higher temperature, it is conceivable that the $\mathrm{Nb}$-precipitates will dissolve back into the matrix in the form of solid solution $\mathrm{Nb}$. Figure $\mathbf{1 0}$ shows the effect of the time of additional reheating treatment at $900^{\circ} \mathrm{C}$ after aging at $700^{\circ} \mathrm{C}$ for $10 \mathrm{~h}$ on the $0.2 \%$ proof strength at $700^{\circ} \mathrm{C}$ and solid solution $\mathrm{Nb}$. As the reheating treatment time at $900^{\circ} \mathrm{C}$ increased, both the proof strength at $700^{\circ} \mathrm{C}$ and the content of solid solution $\mathrm{Nb}$ increased.

\section{Discussion}

\subsection{Effect of $\mathrm{Nb}$ on $0.2 \%$ Proof Strength at $700^{\circ} \mathrm{C}$}

Using the results in Fig. 6 and Fig. 9(a), Figure 11 shows the effect of the content of solid solution $\mathrm{Nb}$ on the $0.2 \%$ proof strength at $700^{\circ} \mathrm{C}$. The content of solid solution $\mathrm{Nb}$ is the value obtained by subtracting the amount of precipitated $\mathrm{Nb}$, as determined by analysis, from the total content of $\mathrm{Nb}$.

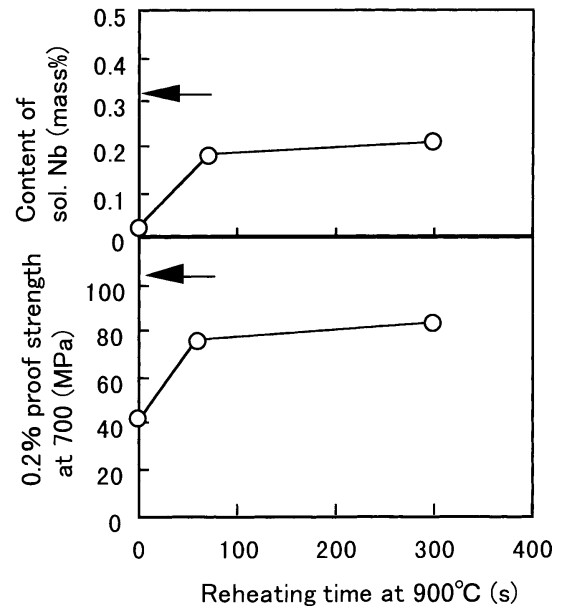

Fig. 10. Effect of reheating time at $900^{\circ} \mathrm{C}$ after aging at $700^{\circ} \mathrm{C}$ for $10 \mathrm{~h}$ on content of sol. $\mathrm{Nb}$ and $0.2 \%$ proof strength at $700^{\circ} \mathrm{C}$. Arrows indicate the values before aging at $700^{\circ} \mathrm{C}$.

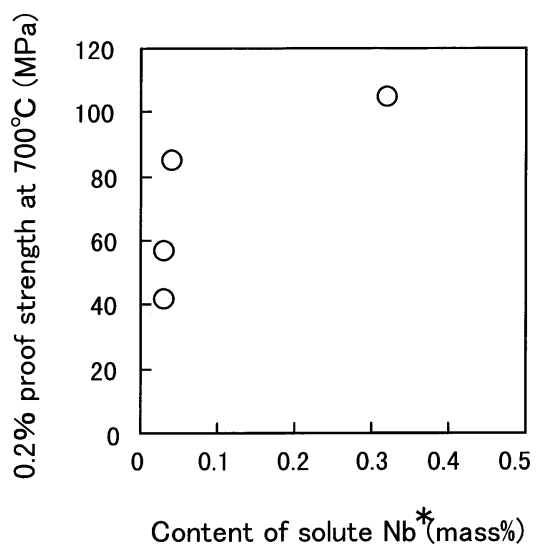

Fig. 11. Influence of solute $\mathrm{Nb}$ after aging at $700^{\circ} \mathrm{C}$ on $0.2 \%$ proof strength at $700^{\circ} \mathrm{C}$. ${ }^{*}$ Total $\mathrm{Nb}(0.46 \%)$-insol. $\mathrm{Nb}$.

In a condition in which it may be thought that substantially no solid solution $\mathrm{Nb}$ exists in the steel after aging at $700^{\circ} \mathrm{C}$ for $2 \mathrm{~h}$ or more, for example, at a solid solution $\mathrm{Nb}$ content level of approximately $0.03 \%$, the $0.2 \%$ proof strength varied greatly, over a range of $85-42 \mathrm{MPa}$. Therefore, it is considered that the content of solid solution $\mathrm{Nb}$ is not the main factor which influences the $0.2 \%$ proof strength at $700^{\circ} \mathrm{C}$. In the steels shown in Fig. 6, Figs. 8(b) and 8(c), a precipitated $\mathrm{Nb}$ content of approximately $0.43 \%$ was identified. In other words, substantially all of the added $\mathrm{Nb}$ had precipitated out, and virtually no solid solution $\mathrm{Nb}$ was present. Considering these results, it is clear that the size and/or inter - particle distance of the fine precipitates of $\mathrm{Nb}$ shown in Figs. 8(b) and 8(c) is the main factor which influences the changes in $0.2 \%$ proof strength at $700^{\circ} \mathrm{C}$ by aging.

As shown in Figs. 9 and 11, the $0.2 \%$ proof strength of the cold rolled and annealed steel that was not given aging treatment was the highest of those in this study. The solid solution $\mathrm{Nb}$ content of this steel is approximately $0.3 \%$. Because the fine $\mathrm{Nb}$ precipitates were not observed before the tensile test in this cold rolled and annealed steel, the possibility that an increase in proof strength was realized as a result ${ }^{9)}$ of the solid solution $\mathrm{Nb}$ content of approximately $0.3 \%$ is conceivable. However, the following results which 
were obtained in this work must also be considered:

(1) After the tensile test at $700^{\circ} \mathrm{C}$ in the cold rolled and annealed steel that was not aged, the fine $\mathrm{Nb}$ precipitates which had not been observed before the tensile test were observed in large quantity (Fig. 5).

(2) Even in a condition in which it is considered that virtually no solid solution $\mathrm{Nb}$ exists in the steel after aging at $700^{\circ} \mathrm{C}$ for $2 \mathrm{~h}$, the $0.2 \%$ proof strength at $700^{\circ} \mathrm{C}$ was high, showing a similar value to that of the cold rolled and annealed steel that was not aged (Figs. 6 and 11).

Based on these results, it is considered that the fine precipitates that formed during tensile test at $700^{\circ} \mathrm{C}$ and/or preceding hold for $20 \mathrm{~min}$ increased the $0.2 \%$ proof strength of the cold rolled and annealed steel, which was higher than that of the steels aged for more than $2 \mathrm{~h}$, in addition to the strengthening by solid solution $\mathrm{Nb}$.

\subsection{Identification of Fine Nb Precipitates after Tensile Test}

It was difficult to identify the fine $\mathrm{Nb}$ precipitates shown in Fig. 5(b) by the electron diffraction pattern because of their fine size. However, as shown in Fig. 6, the mass ratio of the $\mathrm{Nb}$ and $\mathrm{Fe}$ that were newly precipitated as a result of aging at $700^{\circ} \mathrm{C}$ was $1: 1$. Considering the facts that this is near the weight ratio of $\mathrm{Nb}$ and $\mathrm{Fe}$ in the $\mathrm{Fe}_{2} \mathrm{Nb}$ Laves phase, which is $1: 1.2$, and a strong diffraction peak for the $\mathrm{Fe}_{2} \mathrm{Nb}$ Laves phase shown in Fig. 7(b) was also observed in the steels aged for more than $2 \mathrm{~h}$, it may be concluded that the fine $\mathrm{Nb}$ precipitates when cold rolled and annealed steels are given aging treatment at $700^{\circ} \mathrm{C}$ consists mainly of the $\mathrm{Fe}_{2} \mathrm{Nb}$ Laves phase.

In the tensile test of the cold rolled and annealed steel that was not aged, the specimen was held at $700^{\circ} \mathrm{C}$ for 20 min before applying strain, and strain was then applied. Therefore, in explaining the existence of the $\mathrm{Fe}_{2} \mathrm{Nb}$ Laves phase shown in Fig. 8(b), it is considered that the applied strain and/or preceding hold for $20 \mathrm{~min}$ was conducive to precipitation of the above-mentioned $\mathrm{Fe}_{2} \mathrm{Nb}$ Laves phase. From this, it might be concluded that the high $0.2 \%$ proof strength of the $\mathrm{Nb}$-added stainless steel at $700^{\circ} \mathrm{C}$ was attributable to the precipitation of the fine $\mathrm{Fe}_{2} \mathrm{Nb}$ Laves phase.

\section{Conclusion}

The effect of $\mathrm{Nb}$ on $0.2 \%$ proof strength at $700^{\circ} \mathrm{C}$ in $\mathrm{Nb}-$ added ferritic stainless steels was studied. The following results were obtained.

In the sheet of $15 \% \mathrm{Cr}-0.46 \% \mathrm{Nb}$ steel annealed at $1000^{\circ} \mathrm{C}$, solid solution $\mathrm{Nb}$ exists in large quantity. The proof strength of this material at $700^{\circ} \mathrm{C}$ was approximately two times higher than that of the sheet of $15 \% \mathrm{Cr}-0.37 \% \mathrm{Ti}$ steel.

It is considered that one of the reasons for above - mentioned phenomena is fine $\mathrm{Fe}_{2} \mathrm{Nb}$ Laves phase that precipitated during tensile test and/or preceding hold at $700^{\circ} \mathrm{C}$.

\section{REFERENCES}

1) S. Gallo, C. Mus, W. Nicodemi and G. Pontini: Proc. 3rd Eur. Cong. on Stainless Steel '99, AIM, Milan, (1999), 95.

2) J. A. Douthett: Automot. Eng. (1995), 45.

3) M. Yamanaka, Y. Otoguro, F. Miura and T. Zaizen: Seitetsu Kenkyu, 311 (1983), 33.

4) N. Fujita, K. Ohmura, M. Kikuchi, T. Suzuki, S. Funaki and I. Hiroshige: Scr. Mater, 35 (1996), 705.

5) T. Utsunomiya, H. Furuki and T. Adachi: Nisshin Steel Tech. Rep., 71 (1995), 53.

6) A. Miyazaki, K. Ishii and S. Satoh: Kawsasaki Steel Giho, 30 (1998), 99.

7) M. Barteri, M. G. Mecozzi and S. Fortunati: Proc. 3rd Eur. Cong. on Stainless Steel '99, AIM, Milan, (1999), 75.

8) S. Nakamura, N. Hiramatsu, I. Shimizu and Y. Uematsu: Nisshin Steel Tech. Rep., 62 (1990), 128.

9) M. Kikuchi: CAMP-ISIJ, 14 (2001), 689. 